\title{
Obituary of Prof. Avraham Oplatka
}

\author{
Julian Borejdo
}

Published online: 31 August 2011

(C) Springer Science+Business Media B.V. 2011

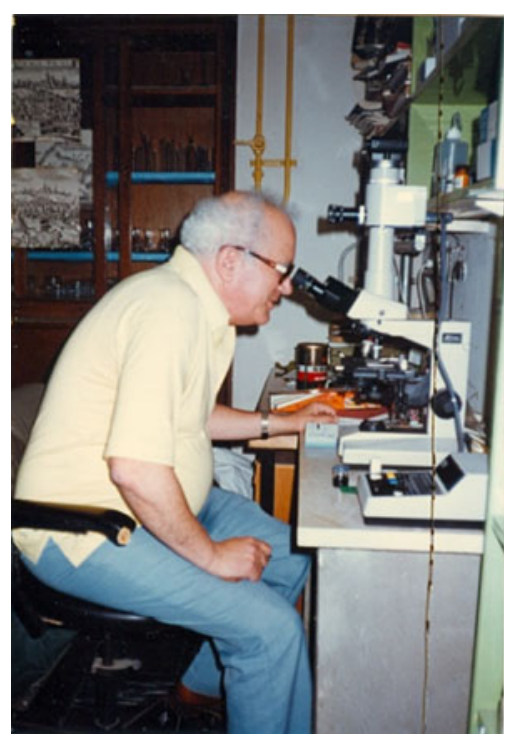

On July 16 the muscle research community lost one of its most brilliant and original thinkers: Prof. Avraham Oplatka passed away in Rehovot, Israel. Avraham was born in Jerusalem, Israel on August 8, 1927. He graduated from high school in 1945 and joined the Haganah, then an underground movement, which is the precursor of today's Israeli Army. Two years later he began studying Chemistry at the Hebrew University of Jerusalem. When Israel was established in 1948 and was attacked by Arab armies, Avraham joined the fledgling Israeli Army as a signal operator and participated in several front line battles for Jerusalem. The city came under a heavy siege and was

J. Borejdo $(\bowtie)$

University of North Texas Health Science Center,

Fort Worth, USA

e-mail: Julian.Borejdo@unthsc.edu saved on June 111948 by the opening of the so-called "Burma Road". It was a road through the countryside, linking Jerusalem with the rest of the country. Avraham was among the first who entered Jerusalem in the convoy through the legendary Burma Road.

Upon the end of the war, Avraham resumed his studies at the Hebrew University of Jerusalem and graduated in 1952. After having heard a lecture by Aharon Katchalsky, he decided to become his student at the Weizmann Institute in Rehovot and to work on the thermoelasticity of open systems. His research showed that the chemical treatment of collagen caused reversible swelling and deswelling, which could be used as a power source in mechanochemical engines (Steinberg et al. 1966). Together with I.Z. Steinberg, he built and patented such an engine (photo below; the machine is at present on loan to the Johns Hopkins University). He received his $\mathrm{PhD}$ in 1962, and soon began independent research on the contraction, of collagen gels (Yonath and Oplatka 1968).

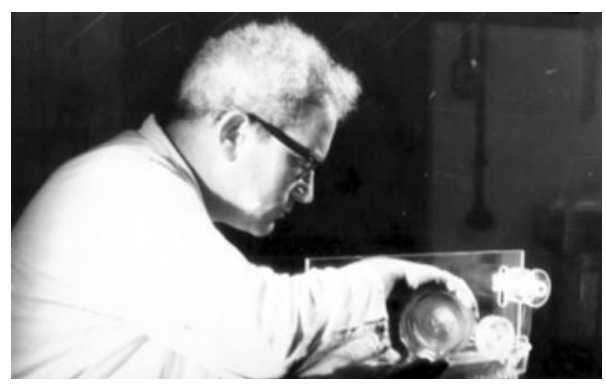

In 1967, he became interested in contraction of what he called an "authentic contractile system"-muscle. He went to Boston to learn as much as possible about the system and soon published, with Eva Szentkiralyi, his first work on muscle proteins on the formation and stability of the 
enzymically active complex of heavy meromyosin with actin (Szentkiralyi and Oplatka 1969). In 1971, he established the Journal of Mechanochemistry and Cell Motilitya predecessor of this Journal. Together with R. Lamed, he made pioneering contributions to the study of the interaction of myosin fragments with immobilized adenosine triphosphate (Lamed et al. 1973). At this time, he came to believe that the movement of water within muscle sarcomeres was intimately involved in the contraction process (Oplatka and Tirosh 1973), which led him to propose that soluble myosin fragments were able to cause muscle contraction (Gadasi et al. 1974).

Avraham was a brilliant, persistent man who strongly believed in his ideas about muscle contraction. His knowledge of various aspects of muscle research was legendary. He always welcomed discussions about his views and those of others. He was generous, supportive and was an inspiring teacher.

\section{References}

Gadasi H, Oplatka A, Lamed R, Muhlrad A (1974) A comparative study of muscle contraction and superprecipitation using trinitrophenylated myosin and active myosin subfragments. Biochem Biophys Res Commun 58(4):913-918

Lamed R, Levin Y, Oplatka A (1973) Enzymatic mechanochemistry. I. The interaction of heavy meromyosin with "immobilized adenosine triphosphate". Biochim Biophys Acta 305(1):163-171

Oplatka A, Tirosh R (1973) Active streaming in actomyosin solutions. Biochim Biophys Acta 305(3):684-688

Steinberg IZ, Katchalsky A, Oplatka A (1966) Mechanochemical engines. Nature 210:568-571

Szentkiralyi E, Oplatka A (1969) On the formation and stability of the enzymically active complexes of heavy meromyosin with actin. J Mol Biol 43(3):551-566

Yonath J, Oplatka A (1968) Mechanochemical melting of collagen fibers. I. Mechanical contractions. Biopolymers 6(8):1129-1145 